Georgetown University Law Center

Scholarship @ GEORGETOWN LAW

2000

\title{
Natural Law as Professional Ethics: A Reading of Fuller
}

David Luban

Georgetown University Law Center, luband@law.georgetown.edu

This paper can be downloaded free of charge from:

https://scholarship.law.georgetown.edu/facpub/1581

David Luban, Natural Law as Professional Ethics: A Reading of Fuller, 18 SOC. PHIL. \& POL'Y 176 (2000).

This open-access article is brought to you by the Georgetown Law Library. Posted with permission of the author. Follow this and additional works at: https://scholarship.law.georgetown.edu/facpub

Part of the Natural Law Commons 


\title{
NATURAL LAW AS PROFESSIONAL ETHICS: A READING OF FULLER*
}

\author{
By David Luban
}

\section{INTRODUCTION}

In Plato's Laws, the Athenian Stranger claims that the gods will smile only on a city where the law "is despot over the rulers and the rulers are slaves of the law." 1 This passage is the origin of the slogan "the rule of law not of men," an abbreviation of which forms our phrase "the rule of law." From Plato and Aristotle, through John Adams and John Marshall, down to us, no idea has proven more central to Western political and legal culture. ${ }^{2}$ Yet the slogan turns on a very dubious metaphor. Laws do not rule, and the "rule of law not of men" is actually a specific form of rule by men (including, nowadays, a few women). These rulers are not slaves to anything. Furthermore, the construction of the slogan-rule of law and not of men - has unfortunate connotations. It suggests that the personal qualities of the human rulers required to secure the rule of law are nothing more than forbearance and disinterestedness - a resolution to stay out of law's way.

What if the rule of law is more demanding than this? What if it turns out to be a particularly elaborate and technically ingenious form of the rule of (let me say) men and women? What if the rule of law establishes a moral relationship between those who govern and those whom they govern? Furthermore, what if sustaining this relationship requires certain moral attitudes and virtues on the part of the governors that are not simply disinterested forbearance, and not simply the moral attitudes and virtues required of everyone?

\footnotetext{
* I have received helpful comments and criticisms from a number of readers, including the other contributors to this volume and participants in the Georgetown University Law Center faculty workshop. In addition, I should like to thank Brian Bix, Ellen Frankel Paul, Fred Schauer, and Wibren van der Burg for extensive written comments on an earlier draft of this essay.

1 Plato, The Laws of Plato, trans. Thomas L. Pangle (New York: Basic Books, 1980), 715d.

${ }^{2}$ Aristotle offers a similar phrase in the Politics, at 1287a1-b1. Jonathan Barnes, ed., The Complete Works of Aristotle (Princeton, NJ: Princeton University Press, 1984), 2:2042. John Adams introduced the phrase "government of laws, and not of men" into America in his 1774 "Novanglus Paper" (no. 7), reprinted in Charles Francis Adams, ed., The Works of John Adams (Freeport, NY: Books for Libraries Press, 1969), 4:106. From there it migrated into the Massachusetts constitution of 1780 and eventually into Justice Marshall's opinion in Marbury o. Madison, 5 U.S. 137 (1803). Fred R. Shapiro, The Oxford Dictionary of American Legal Quotations (New York: Oxford University Press, 1993), 319.
} 
In that case, the rule of law would turn out to rely on the specifically professional ethics of the lawmakers. One might be tempted to call this "political ethics," the ethics of rulers. But that is not quite right. Rulers are not identical with lawmakers. Rulers make decisions and devise policies, but decisions and policies are not yet laws. Embodying decisions and policies in the form of laws is a tricky business, technically difficult in exactly the same way that embodying private parties' intentions in a legal contract is difficult - and the people who carry out each of these lawmaking tasks are (what else?) lawyers. Thus, the rule of law relies on the professional ethics of lawyers (even if they do not call themselves lawyers or belong to the bar).

Finally, what if the professional ethics of lawyer-lawmakers - the moral relationship and attitudes and virtues required by the rule of law-cohere better with laws enhancing human dignity than with laws assaulting it, because enacting laws that assault human dignity tends to undermine the moral relationship that sustains the rule of law? If this were the case, we would be entitled to assert that the rule of law morally constrains the content of laws. This sounds like a natural law theory. We could call it a theory of the "morality of law," provided we understood that the phrase refers to the morality of lawmakers, and only derivatively to the morality of laws. We would have a theory of natural law as professional ethics.

What I have just described is the unfamiliar argument of a very familiar book, Lon Fuller's The Morality of Law (hereafter $M L$ ), first published in $1964 .{ }^{3}$ (Note that in what follows, my page references to $M L$ refer to the revised edition, published in 1969.) I call the argument unfamiliar because readers have typically treated $M L$ as a book on general jurisprudence, not on professional ethics, and have neglected its moral theory to focus on what they regard as analytical claims about "the concept of law." But "the concept of law" is H. L. A. Hart's title, not Fuller's.

As Fuller himself observed in 1969 (ML 188), this misunderstanding is perfectly natural given the state of play in legal theory when he first published $M L$. For several years, he had been engaged in a debate with Hart, beginning with their famous exchange in the Harvard Law Review. Hart weighed in next in The Concept of Law, which Fuller criticized in

${ }^{3}$ I will use the following abbreviations for works of Fuller to which I cite repeatedly: $M L=$ The Morality of Law, rev. ed. (New Haven, CT: Yale University Press, 1969); LQI = The Law in Quest of Itself (Evanston, IL: Northwestern University Press, 1940); PSO = The Principles of Social Order: Selected Essays of Lon L. Fuller, ed. Kenneth I. Winston (Durham, NC: Duke University Press, 1981); PFL = "Positivism and Fidelity to Law-A Reply to Professor Hart," Harvard Law Review 71, no. 4 (February 1958): 630-72; RFCL = "Reason and Fiat in Case Law," Harvard Law Review 59, no. 3 (February 1946): 376-95; RN= "A Rejoinder to Professor Nagel," Natural Law Forum 3, no. 1 (1958): 83-104.

The present essay examines, from a different perspective, themes I discuss in "Rediscovering Fuller's Legal Ethics," published concurrently in Georgetown Journal of Legal Ethics 11, no. 4 (Summer 1998): 801-29; and Willem J. Witteveen and Wibren van der Burg, eds., Rediscovering Fuller: Essays on Implicit Law and Institutional Design (Amsterdam, The Netherlands: University of Amsterdam Press, 1999), 193-225.

${ }^{4}$ H. L. A. Hart, The Concept of Law (Oxford: Clarendon Press, 1961).

${ }^{5}$ H. L. A. Hart, "Positivism and the Separation of Law and Morals," Harvard Law Review 71, no. 4 (February 1958): 593-629. Fuller's reply is $P F L$, cited in full in note 3 above. 
chapter 3 of $M L$. Hart returned the compliment when he reviewed $M L^{6}{ }^{6}$ and Fuller responded in the new appendix he wrote for the revised edition of $M L$. Subsequent readers have naturally assumed that Fuller and Hart were still debating the same issue of whether legal norms are logically distinct from moral norms-an issue framed by Hart in his own terms at the beginning of the debate.

On this assumption, $M L$ gets read approximately as follows. The central argument of $M L$ begins with the famous parable "Eight Ways to Fail to Make Law," found in chapter 2. The parable does two things. First, it provides an analysis of the rule of law into the eight familiar canons that Fuller calls "principles of legality." These hold that laws should exhibit (1) generality (i.e., legislating through rules rather than case-by-case directives), (2) publicity, (3) nonretroactivity, (4) clarity, (5) noncontradictoriness, (6) obeyability in practice, (7) constancy through time, and (8) congruence between the rules as announced and their actual administration (ML 39). Second, the parable argues that when these canons are violated, the result is not bad law, but no law at all. The canons, then, are necessary conditions on the concept of law. They are also, or so Fuller claims, an "inner morality of law"; because they have to do with the promulgation of laws, not with their content, this inner morality is a "procedural natural law." There is also a substantive natural law, but Fuller leaves the connection between the procedural and substantive branches of natural law obscure. And that's about it.

How do those who read Fuller this way react to his argument? They generally like his analysis of the rule of law, which ranks alongside comparable efforts by John Rawls and Joseph Raz. ${ }^{7}$ Many accept the idea that without these canons there can be no law at all; however, most reject the claim that the canons represent principles of morality, inner or otherwise. It is this latter claim that forms the crux of the issue between Fuller and Hart, and the dominant view seems to be that Fuller was wrong.

Undoubtedly, that latter claim is important. But reading Fuller in the manner described above slides over his treatment of substantive natural law, and treats the first chapter of $M L$, on ethical theory, as if it does not exist. As a result, the argument about professional ethics with which I began simply disappears from the reading entirely. And that is too bad, because in important ways (not every way) Fuller's argument is right.

\section{II. "The Word 'Law' Means the Life Work of the Lawyer"}

Fuller never disguises his intentions. He says in $M L$ that he will offer only one definition of law: "the enterprise of subjecting human conduct

${ }^{6}$ H. L. A. Hart, "Book Review - The Morality of Law," Harvard Law Review 78, no. 6 (April 1965): 1281-96.

${ }^{7}$ John Rawls, A Theory of Justice (Cambridge, MA: Harvard University Press, 1971), 23543; Joseph Raz, "The Rule of Law and Its Virtue," Law Quarterly Review 93, no. 2 (April 1977): 195-211. 
to the governance of rules" (ML 106). His title, The Morality of Law, then, must be paraphrased thus: "the morality of the enterprise of subjecting human conduct to the governance of rules." Fuller explicitly calls attention to the fact that his definition classifies law as an activity rather than, say, a set of propositions of law, or a distinctive kind of social norm. The activity of subjecting human conduct to rules, unlike the activity of governing one's own conduct in accordance with rules, is performed specifically by the rule-designer. "So when I speak of legal morality, I mean just that. I mean that special morality that attaches to the office of law-giver and law-applier." ${ }^{8}$ He labels this a "role morality," and likens it to the distinctive ethics of lawyers - it is "no mere restatement of the moral principles governing human conduct generally, but ... special standards applicable to the discharge of a distinctive social function" (ML 193; see also PSO 201). In the second edition of $M L$, Fuller complains that "no modern positivist elevates to a central position in his thinking any limitations contained in "the law job" itself" (ML 192). The "law job" is performed by the lawyer, whom he elsewhere calls the "architect of social structure" (PSO 50-52, 253, 264-70). This makes clear that $M L$ is a book about professional ethics-specifically, the professional ethics of those lawyers Fuller refers to as lawgivers and law-appliers. ${ }^{9}$

This way of thinking about law was already evident in 1940, when Fuller first discussed natural law and positivism in The Law in Quest of Itself. After rehearsing the definitions of law offered by several philosophical schools, he considers the obvious concern that debates among them amount to little more than terminological hairsplitting. Here is how he responds:

Yet if in these definitions the word "law" means the life work of the lawyer, it is apparent that something more vital than a verbal dispute hinges on the choice between them. Surely the man who conceives

${ }^{8}$ Lon L. Fuller, "A Reply to Professors Cohen and Dworkin," Villanova Law Review 10, no. 4 (Summer 1965): 660. He employs similar phrasing at ML 206.

${ }^{9}$ I do not mean that Fuller literally thought all legislators are professional lawyers. He understood, of course, that nonlawyer legislators decide on what should become law before turning it over to lawyers for drafting. He emphasized that the lawmaking job has a technical side, because embodying policies in effective rules is difficult in exactly the way that embodying parties' intentions in a well-wrought contract is difficult. Negotiating these difficulties is precisely the special craft of lawyers. Fuller also argued that the technical aspect of lawmaking imposes substantive constraints on what policies can be embodied in laws, because human activity "always involves a reciprocal adjustment between ends and means." Lon L. Fuller, "The Philosophy of Codes of Ethics," Electrical Engineering 74, no. 5 (October 1955): 916. See Fuller's "Means and Ends," in PSO, 52-58. Not every conceivable end can be turned into workable law. In this sense, all legislation requires the exercise of lawyerly skills, even when the legislator is not a lawyer. The reciprocal adjustment of ends and means likewise implies that a transactional lawyer papering a deal shapes it rather than serving as a mere scrivener: lawyering requires the exercise of legislative skills, even when the lawyer is not a legislator. It follows that the roles of legislators and lawyers are closer than appears at first sight, and this overlap matters to Fuller-it is one of the points of his King Rex parable. Hence my talk of lawyers in the text. 
his task as that of reducing the relations of men to a reasoned harmony will be a different kind of lawyer from one who regards his task as that of charting the behavior of certain elderly state officials. (LQI 3-4)

"The word 'law' means the life work of the lawyer." This is not just a rhetorical hook to capture the interest of the law school audience to which he was lecturing. It is, in paraphrase, the very definition he employs in $M L$.

In the second sentence of the quotation from $L Q I$, Fuller offers his own characterization of natural law, or rather, of the activity of the natural law lawyer: "reducing the relations of men to a reasoned harmony." On its face, this is strikingly different from the most common understanding of natural law in analytic jurisprudence. Analytic philosophers of law tend to regard natural law and positivism as competing theses about the relation between legal and moral propositions. Jules Coleman's careful definition is a good example: on his account, positivism is the "proposition that there exists at least one conceivable legal system in which the rule of recognition does not specify being a principle of morality among the truth conditions for any proposition of law." ${ }^{10}$ Natural law, then, is the view that in every conceivable legal system, the rule of recognition (the rule by which we recognize valid laws) specifies that being a principle of morality is among the truth conditions for any proposition of law.

Fuller characterizes natural law as a way of conducting a practical activity - "reducing the relations of men to a reasoned harmony" rather than as a philosophical thesis about the truth conditions of propositions of law. For Fuller, there is not really a thesis associated with natural law at all ( $R N$ 84). Of course, Fuller believes that there is a characteristic morality associated with the "law job" ( $M L$ 192). But this marks an important shift in emphasis. Where other writers on all sides of the positivism/natural law debate understand the phrase "the morality of law" to refer to the morality of laws, for Fuller it refers to the morality of lawmaking.

This usage, which is quite consistent in Fuller's work, is bound to create confusions for those who assume that the phrase "the morality of law" refers not to the moral code of the rule-designer but rather to the moral content of legal rules. In particular, it means that when positivists deny that the law has any necessary moral content, Fuller tends to hear them asserting that no moral code governs lawgiving, a claim that he finds preposterous. Positivists, however, do not really intend to make this claim. Similarly, when Fuller insists that there is a morality to law, his critics assume that he is making a conceptual claim about the necessary

${ }^{10}$ Jules L. Coleman, "Negative and Positive Positivism," in Marshall Cohen, ed., Ronald Dworkin and Contemporary Jurisprudence (Totowa, N]: Rowman and Allenheld, 1983), 31. This is Coleman's definition of "negative" (that is, minimal) positivism. 
connection between legal rules and morality, rather than arguing that lawmaking is a profession with a distinctive professional ethics. But it is the latter that Fuller means.

I said earlier that Fuller classifies lawgivers and law-appliers (legislators and judges) together with lawyers. ${ }^{11}$ This will seem puzzling until we realize that Fuller invariably has in mind transactional lawyers, not litigators (who, he observes, are a small minority of the legal profession [PSO 252-53]). As noted above, Fuller views the lawyer as an "architect of social structure"; he regards litigation, the recourse when social structure fails, as a poor-even perverse-focus for understanding what makes lawyers' work important. It would be like trying to understand an educator's work by focusing on the process of disciplining classroom troublemakers, or trying to understand marriage by examining divorce. ${ }^{12}$

Three characteristics of the transactional lawyer make him the paradigm jurist in Fuller's eyes. First, his job is to facilitate interaction between two or more private parties - and facilitating interaction is, for Fuller, the principal aim of law. Second, although the transactional lawyer advises his client, sometimes quite forcefully - he is not merely a mouthpiece or a scrivener-he understands that the client, not the lawyer, is the person who has to do the interacting after the deal is made. This is the fundamental moral fact about the relationship. Third, the transactional lawyer facilitates the interaction by drawing up a framework of rules-a contract, the transactional equivalent of a piece of legislation. ${ }^{13}$

\section{Excellences as Powers: "Sin Is}

\section{A Sinking InTo Nothingness"}

When we fully appreciate that The Morality of Law is a book about professional ethics rather than a traditional treatise on jurisprudence, we can better understand why Fuller begins the book with a chapter on ethical theory, and why the chapter opens with contrasting definitions of ' $\sin$ ', rather than, say, justice or injustice. Talk about sin would be strange

${ }^{11}$ On this point, see also Kenneth I. Winston, "Legislators and Liberty," Law and Philosophy 13, no. 3 (August 1994): 393-96.

12 These analogies are mine, not Fuller's. Although transactional lawyers must anticipate possible litigation, "battening down the hatches against possible future litigation" (PSO 253) cannot be their principal job as they draft contracts. The clients are trying to get something done, not merely avoid losses when their projects shipwreck. Fuller more than once quotes Aquinas's dictum that if the highest duty of a captain were to preserve his ship, he would keep it in port forever. Aquinas, Summa Theologiae, I-II, q. 2, a. 5, quoted at PSO 56, ML 185.

I discuss Fuller"s conception of lawyers' work more fully in "Rediscovering Fuller's Legal Ethics," 810-19.

${ }^{13}$ Fuller argues, strikingly, that the terms contained in a contract are just as much law as the rules governing the formation of contracts. PSO 174-75. He is a legal pluralist-someone who believes that there are many legal systems in a society, not just the big legal system administered by the state: on this account, both private actors and the state can make law. Fuller argues explicitly for legal pluralism at $M L$ 123-29. 
if the subject were the morality of laws, rather than the morality of lawmaking. Because Fuller is focusing on the latter, however, he is interested in the ways lawyers can sin against the enterprise in which they are engaged. To an unusual extent, Fuller personalizes jurisprudence: he sees acts of legislation and interpretation as products of lawgivers and lawappliers, products whose quality depends crucially on the people who make them.

Fuller's moral theory turns on a distinction between the morality of duty - "the most obvious demands of social living" (ML 9)-and the morality of aspiration - "the morality of the Good Life, of excellence, of the fullest realization of human powers" (ML 5). Several points stand out.

1. There is, first of all, the idea that aspiration has a morality. This is hardly an obvious point. Many of our aspirations fall under the general heading of things that it would be nice to do, but there is nothing especially moral about the category of the 'that-would-be-nice'. It would be nice if I could play the piano, speak German, and work the exercises in the old mathematics textbooks that have been hibernating on my shelf since college. All these things being among my interests, it is natural to think of them as aspirations. But it would be odd for anyone to take me to task for my failings at piano, German, and mathematics, and equally odd for me to feel ashamed about them. In contrast, speaking of moral failings implies, at the minimum, a dimension of blame and shame: moral failings are among those failings that do deserve criticism (from both oneself and others). Otherwise, why call them moral failings? From a moral outlook centered on rights and duties, "mere" aspiration is a nonmoral phenomenon; Fuller's claim to the contrary marks out a distinctive moral position.

2. Kant believed that we lie under a duty to improve ourselves; this and the duty to promote others' happiness are the principal obligations he elaborates in the "Doctrine of Virtue." 14 These two duties roughly correspond with Fuller's categories, but Fuller rejects the reduction of aspiration to duty ( $M L 5$ ). Instead, he finds that criticism appropriate to the morality of aspiration involves terms like "failure" and "shortcoming, not ... wrongdoing," as well as assertions that one has not engaged in "conduct such as beseems a human being functioning at his best" (ML 5; see also $M L 3$ ). In other words, the morality of aspiration employs the vocabulary of human excellence - what philosophers call 'aretaic' concepts rather than 'deontic' concepts, the vocabulary of right or wrong action. In that sense, the morality of aspirations lies very close to contemporary

${ }^{14}$ See generally Immanuel Kant, "The Doctrine of Virtue," in Kant, The Metaphysics of Morals, trans. Mary Gregor (Cambridge: Cambridge University Press, 1991). The treatise is divided into two principal sections: "On Duties to Oneself as Such" and "Duties of Virtue to Others." See also Marcia Baron, "Kantian Ethics," in Marcia Baron, Philip Pettit, and Michael Slote, Three Methods of Ethics: A Debate (Malden, MA: Blackwell, 1997), 13-21. 
virtue ethics, the view that places aretaic concepts at the heart of moral theory. ${ }^{15}$

3. When is it appropriate to treat aspirations morally, rather than merely as things it would be nice to do? Fuller never explicitly addresses this question, but the use to which he puts the distinction suggests one important answer: our aspirations have a moral dimension whenever other people's well-being depends on them. Paradigmatically, this will be true in the sphere of work, and specifically in the professions. It is hardly coincidental that aretaic concepts evolved in Greek thought to characterize warriors, whose excellences and failures meant the difference between prosperity and disaster for those who relied on them. ${ }^{16}$ In more peaceable societies, we continue to think "aretaically" when we choose a surgeon or a lawyer. We want something more than dutifulness, which after all is merely the requirement for avoiding malpractice liability. We want someone who strives for professional excellence and attains it. We criticize professionals who fail for want of excellence, along with those who do not even strive for it. This is moral criticism, and it is based in the morality of aspiration.

Even when no one else's well-being depends directly on our work (as is true, for example, in the writing of philosophy), the morality of aspiration applies in a derivative way. It would (merely) be nice if I could play the piano; playing the piano is, for me, a nonmoral aspiration. But, as a writer on philosophical topics, it is a more serious failing that my German is not good enough to read Kant or Hegel. If my philosophizing is slipshod, that is an even more serious failing. Here, the morality of aspiration applies.

In general, it seems, aspiration "goes moral" when our aspirations tie in to serious commitments, when they move from the amateur to the professional. Fuller is in love with the idea of professionalism. He celebrates the virtues of excellence in work; in this respect, his nearest literary counterpart is Primo Levi in The Monkey's Wrench and The Periodic Table. ${ }^{17}$ Thus, the third point that emerges from Fuller's "two moralities"

${ }^{15}$ For an alternative approach to Fuller's theory, see Wibren van der Burg, "The Morality of Aspiration: A Neglected Dimension of Law and Morality," in Witteveen and van der Burg, eds., Rediscovering Fuller, 174-80. Van der Burg focuses on Fuller's claim that the moralities of duty and aspiration lie on a single continuum ( $M L 9-10)$, but I believe that this was a mistake on Fuller's part. The continuum image implies that there will be some point above which everything is aspiration and below which everything is duty. However, ideals such as always doing my duty, never being negligent or unfair for even a single second, or leading a perfectly blameless life belong simultaneously to the morality of duty and the morality of aspiration: to deviate from these ideals violates the morality of aspiration, but by definition each deviation also violates a duty. Hence, the continuum metaphor must be incorrect. For this reason, I emphasize the categorical differences between aspiration and duty.

${ }^{16}$ A. W. H. Adkins, Merit and Responsibility: A Study in Greek Values (Oxford: Clarendon Press, 1960), 30-60.

${ }^{17}$ Primo Levi, The Monkey's Wrench, trans. William Weaver (New York: Penguin, 1987); Primo Levi, The Periodic Table, trans. Raymond Rosenthal (New York: Schocken, 1984). 
discussion-alongside the ideas that aspiration has a morality, and that its morality is a kind of virtue ethics - is the thought that professional ethics includes the morality of aspiration as one of its central features.

4. Next, consider the quotation with which Fuller begins the first chapter of $M L$ : "Sin is a sinking into nothingness" $(M L 3) .{ }^{18}$ The absence of excellence, of virtue, is not badness so much as nonbeing. This is a familiar Platonic and Augustinian idea, and I think it is quite false as a general account of evil. It makes a great deal of sense, however, when applied to aretaic concepts such as "virtue" (a word that for Fuller has the "original sense of power, efficacy, skill, and courage" [ML 15]). If a lawyer is not doing any of the things a good lawyer does, she is not merely practicing law badly. She is not practicing law at all. Virtues are functional excellences, and a professional role is defined by its functions; take away enough of the professional virtues, and the result is simply not recognizable as the professional role.

It should be clear why these four major points are important to understanding Fuller's jurisprudential argument. I have been claiming that Fuller's morality of law is a set of excellences that belong to the professional ethics - the role-morality - of lawmakers. This is specifically true of the inner morality of law: Fuller's eight canons of lawmaking. It is significant, after all, that Fuller introduces the canons with the parable of King Rex, who aimed "to make his name in history as a great lawgiver" (ML 34) - an entirely aretaic ambition. As Fuller tells the story, moreover, Rex's failures led him repeatedly to reflect not on the concept of law, but on his own personal failings - further evidence that Fuller's focus is on the legislator, not the legislation. ${ }^{19}$ If sin is a sinking into nothingness, then we can understand Fuller's famous conclusion that Rex "never even succeeded in creating any law at all, good or bad" (ML 34) in a somewhat nonstandard light. It becomes an observation about the role-morality of law-giving rather than an analytical claim about necessary conditions on the very concept of law. Fuller is simply pointing out that whatever King Rex did when he issued directives in a fashion that entirely lacked the characteristic excellences of the lawgiver's craft, he was not subjecting human conduct to the governance of rules. He was not making law.

These observations derive from a more general point about what I will call purposive concepts - concepts that define objects by the functions they serve in fulfilling purposes. For example, 'light switch' is a purposive con-

18 "Der Sünde ist ein Versinken in das Nichts." Significantly, Fuller says he may have imagined this quotation, an admission that suggests how central it is to his outlook.

${ }_{19}$ Consider, for example, these statements found in the parable: "His first move was to subscribe to a course of lessons in generalization" (ML 34); "Rex undertook an earnest inventory of his personal strengths and weaknesses" (ML 35); "Continuing his lessons in generalization, Rex worked diligently. ..." (ML 35); "Recognizing for the first time that he needed assistance...." (ML 36); "By now, however, Rex had lost his patience with his subjects" ( $M L 36)$; "Reflecting on the misadventures of his reign, he concluded. ." (ML 37). 
cept: it defines objects by their function of turning lights on and off. ${ }^{20}$ Fuller's fundamental insight into purposive concepts is that to identify an object purposively is implicitly to specify a standard of success and failure. Fuller puts this strikingly when he writes that the concept of a steam engine "overlaps mightily" with the concept of a good steam engine (LQI 10-11). 'Steam engine' is a purposive concept: what makes devices steam engines is their ability to convert steam power to usable mechanical energy. What a steam engine is good for and what a steam engine is "overlap mightily."

This point carries the important consequence that when we use purposive concepts in descriptions, we are automatically evaluating as well as describing. Take a simple example. Touring a house, I notice an odd-looking bump on the wall. It can be wiggled from side to side, but wiggling it does nothing whatsoever. I'm puzzled. Suddenly I recognize that the bump is a broken light switch. This is one single recognition, not two: to identify the bump as a light switch is simultaneously to identify it as a defective light switch. If I have no idea that a light switch that does not turn the lights on or off is defective, I lack the concept 'light switch' altogether. ${ }^{21}$

The way that Fuller usually phrases this point is to say that the is and the ought cannot be sharply distinguished, or that they merge. This is a maddeningly elusive way of putting things, and even Fuller recognized that "phrases like 'a merger of fact and value' are unsatisfactory" (RN 83). The reason such phrases are unsatisfactory is that they wrongly suggest that to describe something as a steam engine is already to describe it as a good steam engine. This is certainly not what Fuller means to say. Substitute the word 'law' for 'steam engine' and this sort of misinterpretation is disastrous.

As I interpret them, such phrases instead assert that to recognize something as a steam engine or a light switch is already to recognize what it ought to do, to recognize a built-in standard of success or failure. Success or failure at what? At being a steam engine or a light switch - at being what it is, one might say. Purposive concepts are aspirational concepts - and now we recognize that Fuller's morality of aspiration is intimately connected with his analysis of purposive concepts, and hence with the is/ought distinction.

This point can be turned around. If an object is so bad at converting steam power to mechanical energy or turning lights on and off that we cannot even recognize it as unsuccessfully doing these things, then we will be unable to recognize the object as a steam engine or light switch at all. The worse things get at fulfilling the purposes of steam engines and light switches, the closer they get to the threshold between being a bad steam

${ }^{20}$ Defining objects purposively is a special case of functional definition; it is not the only case, of course, because there are also functional concepts defining objects by the roles they play in nonpurposive processes. For chemists, 'catalyst' is a functional concept, but it is not purposive, because chemical reactions are not purposes.

${ }^{21}$ Fuller argues that omitting the purpose in descriptions of purposive objects makes them misdescriptions. Lon L. Fuller, "Human Purpose and Natural Law," Natural Law Forum 3, no. 1 (1958): 68-70. 
engine or light switch and not being a steam engine or light switch at all. Sin is a sinking into nothingness.

One more point about the evaluative dimension of purposive concepts turns out to be crucial to Fuller's understanding of the morality of law. There is nothing distinctively moral about converting steam power to usable mechanical energy or turning lights on and off-so the "merger of is and ought" in these examples is not quite a merger of fact and value. Matters are different, however, when the purposively defined entity is a person defined through her social or occupational role ('parent', 'physician', 'lawyer', 'lawmaker'), and the means by which she fulfills the role's purposes create a long-term moral relationship with other people. In such cases, the standard of success implicit in the purposive concept is not just fulfillment of the occupation's ends narrowly conceived. Instead, the standard of success is fulfillment of these ends in a manner consistent with the moral relationship, for if the role-occupier chronically betrays the moral relationship, the other parties will dissolve it. Under this standard, a relationship that originates only as a means to an end becomes incorporated into the end itself.

\section{IV. "The Citizen's Role as a Self-Determining Agent"}

According to Fuller, when a lawmaker systematically violates any of the canons of the internal morality of law - the role-morality of his or her job-the result is not law ( $M L$ 39). What, then, if not law, is it? Fuller seems to think that there are two characteristic answers to this question. His first answer emerges when he discusses the Nazi legal system or other criminal legal systems. In this discussion, he leaves little doubt that he considers these systems as nothing more than Hart's illegitimate "gunman writ large" -examples of raw power disguised as law.

However, violating the eight canons need not be illegitimate in the way that the gunman writ large is illegitimate. Fuller's second answer is that law must be distinguished from "managerial direction" (ML 207) - a form of governance that is perfectly legitimate in many everyday contexts, but that involves no commitment to the canons of generality or congruence between official action and declared rule. ${ }^{22}$ Managerial direction is a form of governance, but it is not the enterprise of subjecting human conduct to the governance of rules, because managerial directives are not necessarily rules: a manager can deviate from his own general directives whenever circumstances require.

${ }^{22}$ Fuller mistakenly asserts that the issue of nonretroactivity never arises in managerial direction, because no manager would ever order someone today to do something yesterday (ML 209). However, a manager might find it quite expedient to change a policy retroactively. For example, a manager might decide to deduct the costs of tools that workers damage from their pay, and it is easy to imagine circumstances in which the manager might wish to make this policy retroactive. If the terms of employment do not protect workers from policies like this, and if there is no labor union to fight the policy, we can readily imagine that the manager will be successful. Thus, Fuller's point should have been that in a managerial context, there is no necessary moral commitment to nonretroactivity. 
Usually, when Fuller asserts that governance that systematically violates the eight canons is not law, the way to understand the phrase "not law" is as an abbreviation for "not law but tyranny" or "not law but managerial direction." 23 (The distinction between tyranny and managerial direction is that in the latter, but not the former, subordinates share their superiors' aims.) For Fuller, the "identification of law with every conceivable kind of official act" (ML 169) is a conceptual mistake that leads to misunderstandings about the morality of law. ${ }^{24}$

In particular, Fuller argues that governing the conduct of others through law rather than managerial direction is itself a morally freighted choice. According to Fuller, it implies "a certain built-in respect for [the] human dignity" of those subject to the law ("the governed," as I shall call them for short), in a way that managerial direction does not. ${ }^{25}$ This is the case for several reasons.

First, it recognizes that the form of governance will not be by momentby-moment direct supervision. Governance through general rules, unlike managerial direction, presumes a measure of respect for the moral powers of the governed. "To embark on the enterprise of subjecting human conduct to the governance of rules involves of necessity a commitment to the view that man is, or can become, a responsible agent, capable of understanding and following rules, and answerable for his defaults" (ML 162). Elsewhere, Fuller makes the Wittgensteinian point that legal rules cannot explicitly exclude all aberrant interpretations in advance, and concludes that relying on the governed to follow rules presupposes shared "notions of the limits of legal decency and sanity." 26 Governance through rules implies that the governed and the governors belong to the same interpretive community and have roughly equivalent powers of intellect and will.

Second, governance through general rules, unlike specific directives, presupposes the autonomy of the governed. "The law does not tell a man what he should do to accomplish specific ends set by the lawgiver; it furnishes him with baselines against which to organize his life with his fellows. . . Law provides a framework for the citizen within which to live his own life" (PSO 234). ${ }^{27}$ Elsewhere, Fuller describes "the view of man implicit in legal morality" (ML 162) as "the citizen's role as a self-

${ }^{23}$ The one notable exception is the King Rex parable itself. There, the hapless king is neither a manager nor a tyrant-he is merely an incompetent.

${ }^{24}$ Here (and in other places) my reading is influenced by Jeremy Waldron, "Why LawEfficacy, Freedom, or Fidelity?" Law and Philosophy 13, no. 3 (August 1994): 259-84.

${ }^{25}$ Fuller, "A Reply to Professors Cohen and Dworkin," 665.

${ }^{26}$ Lon L. Fuller, Anatomy of the Law (New York: Praeger, 1968), 63.

${ }^{27}$ Fuller makes the same point in $M L:$ : "LL]aw furnishes a baseline for self-directed action, not a detailed set of instructions for accomplishing specific objectives." ML 210. He also uses the "baseline" terminology to make the converse point, namely, that not only does law presuppose the goal-setting freedom of the governed, but that the goal-setting freedom of the governed requires law. "To live the good life ... requires the support of firm base lines for human interaction, something that-in modern society at least-only a sound legal system can supply." ML 205. He elaborates this latter point in "Freedom-A Suggested Analysis," Harvard Law Review 68, no. 8 (June 1955): 1305-25. 
determining agent" (ML 166). To be a lawgiver rather than a commandgiver is to treat the citizen as a self-determining agent.

Governing through general rules also implies a certain impersonality in the relationship between governors and governed. Each individual falls under a rule only as a member of a general class, and each action is likewise judged only on the basis of general characteristics. What matters is what we are and do, not who we are-our deeper identity remains outside law's purview. Government through general rules contrasts starkly with the patrimonial familiarity that breeds contempt; law treats us as 'Sie' rather than ' $d u$ ', as 'vous' rather than ' $t u$ '.

Third, governance through rules, unlike the gunman writ large, assumes a measure of self-enforcement and self-monitoring on the part of the governed. Governance through rules, which is relatively cumbersome, would be unnecessary if an enforcer were always present. Although a tyrant can dominate a hostile population using a surprisingly small number of police-by making it extremely dangerous to even attempt to organize resistance that could overwhelm the police force-governance through rules presumes at least the passive cooperation of the governed ( $M L 216) .^{28}$

Respect for the governed, respect for the autonomy of the governed, and trust in the governed - these are the three overlapping moral values underlying a governor's choice of law, rather than managerial direction, as the specific form of governance. Fuller's point, then, seems to be that embarking on the enterprise of subjecting human conduct to the governance of rules creates a certain kind of moral relationship between governor and governed. It is, specifically, a relationship in which a governor abjures the streamlined efficiency of managerial direction in favor of trusting the governed to understand and follow general rules on their own.

Once we see this point, a puzzling passage from The Morality of Law begins to make sense. Many of Fuller's critics complain that Fuller's eight principles of legality are merely conditions of efficacy, not moral principles. They accept that Fuller's King Rex parable demonstrates that governors must follow the eight canons if they want people to obey their laws. These critics argue, however, that this is true whether the laws in question are good or evil, and thus that the canons themselves have nothing to do with morality. To illustrate the point, Hart observes that there are also rules of effective poisoning. Dworkin makes the same point with blackmail and genocide; Marshall Cohen, with murder; and Schauer, more recently, with lynching. ${ }^{29}$

${ }^{28}$ For an illuminating explanation of how even widely hated police states can maintain their dominance using a surprisingly small number of enforcers, see Russell Hardin, One for All: The Logic of Group Conflict (Princeton, NJ: Princeton University Press, 1995), 29-32.

${ }^{29}$ Hart, "Book Review - The Morality of Law," 1286; Ronald Dworkin, "Philosophy, Morality, and Law-Observations Prompted by Professor Fuller's Novel Claim," University of Pennsylvania Law Review 113, no. 5 (March 1965): 676; Ronald Dworkin, "The Elusive Morality of Law," Villanova Law Review 10, no. 4 (Summer 1965): 634; Marshall Cohen, "Law, Morality, and Purpose," Villanova Law Review 10, no. 4 (Summer 1965): 651; Frederick Schauer, "Fuller's Internal Point of View," Law and Philosophy 13, no. 3 (August 1994): 302-4. 
Fuller responds strangely: "I must confess that this line of argument struck me at first as being so bizarre, and even perverse, as not to deserve an answer" (ML 201). But what is so bizarre and perverse about it? Fuller himself insists that his eight canons are principles of efficacy ( $M L 155-56)$; indeed, when he introduced the idea of an internal morality of law in his 1958 reply to Hart, he argued for its canons solely on grounds of efficacy (PFL 644-45).

What strikes Fuller as perverse about the accusation that he has confused morality with efficacy is that he regards the choice to govern through law rather than managerial direction as a sacrifice of efficacy for moral ends (ML 202-3). To put the point another way: while Fuller agrees that the principles of legality are instrumentally necessary to make governance by law effective ( $M L 155-56$ ), he thinks that governing by law rather than managerial direction represents a sacrifice of expediency in the name of principle. The ultimate justification of the principles of legality is therefore moral, not instrumental. Fuller finds the poisoning and blackmail analogies perverse because they assume that an evildoer would for some mysterious reason choose as an instrument of evil a relatively ineffective tool-a tool, moreover, that is relatively ineffective because it displays precisely the kind of moral regard for its victim that an evildoer lacks. ${ }^{30}$

Consider, by analogy, a professor's decision to teach a large class through the Socratic method of eliciting the classroom material by questioning students rather than by straight lecture. (The analogy is mine, not Fuller's.) The Socratic method is much less efficient than lecturing, and much harder to do well. It sacrifices coverage of material, it frequently frustrates and puzzles students, and it makes classroom progress hostage to the commitment and capabilities of the class. Why, then, would a teacher choose the Socratic method? The principal reason is that teachers wish to train their students in the art of analyzing issues for themselves, along with the art of explaining their own thinking, in public, on their feet. The point of Socratic teaching is to cultivate the students' active powers, even at the cost of efficiency. This is very similar to what Fuller takes to be the point of governance through law: to cultivate activity rather than passivity, to enhance rather than restrict the citizens' powers of self-determination, even though self-determination is unruly and therefore inefficient.

\footnotetext{
${ }^{30}$ As I read Fuller's argument, it is precisely the argument offered by John Finnis in his exposition of Fuller: "Adherence to the Rule of Law (especially the eighth requirement, of conformity by officials to pre-announced and stable general rules) is always liable to reduce the efficiency for evil of an evil government, since it systematically restricts the government's freedom of maneuver." Finnis, Natural Law and Natural Rights (Oxford: Clarendon Press, 1980), 274. Thus, "[a] tyranny devoted to pernicious ends has no self-sufficient reason to submit itself to the discipline of operating consistently through the demanding processes of law, granted that the rational point of such self-discipline is the very value of reciprocity, fairness, and respect for persons which the tyrant, ex hypothesi, holds in contempt." Ibid., 273.
} 
Socratic teaching is also subject to characteristic abuses that are quite analogous to the abuse of law by tyrants. When a teacher really has a lecture idea in mind, but tries to elicit it through Socratic questioning, she will find herself compelled to deal brusquely with student answers that do not take the discussion where she wants it to go. She will cut corners to guide the discussion, and students will quickly perceive that they are involved in a Socratic shell game of guessing what the teacher has in mind, not in cultivating their own powers. They will rightly view this as a betrayal of the teacher-student relationship: the teacher here is merely pretending to respect the students' intellectual autonomy and cultivate their powers; in reality, she is dominating them. ${ }^{31}$

Does Fuller mean to deny, then, that a lawmaker may have domination on his mind? Not at all. ${ }^{32}$ His conclusion is substantially more interesting than that. Fuller argues that every exercise of social power requires some reciprocity. Even a blackmailer has to exercise some restraint; otherwise, his victim might elect to reveal his own shameful secret in order to bring the bite to an end. Here, Fuller observes, we can imagine the blackmailer pleading with the victim not to do this, and promising to be less greedy in the future (PSO 195-96). Elsewhere, Fuller suggests that a tyrant will find that domination will be easier if he enlists his subjects' cooperation by enhancing their freedom and happiness. ${ }^{33}$ If a lawmaker persistently abuses his relationship with the governed, he will be unable to count on the governed to interpret and follow rules; therefore, a decision to govern through rules rather than orders, perhaps undertaken initially because the order-giver cannot be everywhere at once, imposes moral constraints on the order-giver. The more that the power-holder turns tasks over to the subordinate for his own convenience, the more he makes himself dependent on the agency and independence of the subordinate. In that case, reciprocity tends toward at least rough equality, and one-way projection of authority becomes two-way interaction. ${ }^{34}$

\footnotetext{
${ }^{31}$ A famous philosophy professor (no names, please) was a legendary practitioner of the Socratic shell game, and generations of students parodied his teaching with the following dialogue. Professor: I'm thinking of a number between 1 and 500. Mr. A, please tell me the number. Student A: 15? Professor: No. Ms. B? Student B: Um, is it 96? Professor (fiercely): Ms. $\mathrm{B}, \mathrm{I}$ asked you to name the number between 1 and $500 \mathrm{I}$ am thinking of. Do you really think you've answered my question? Mr. C, tell us the number. Student C: 216 . Professor: That is correct. Ms. B, now do you see your mistake?

The professor was widely regarded as an unforgivable intellectual bully.

32 "I have never asserted that there is any logical contradiction in the notion of achieving evil, at least some kinds of evil, through means that fully respect all the demands of legality." Fuller, "A Reply to Professors Cohen and Dworkin," 664.

${ }^{33}$ See Lon Fuller, "Freedom as a Problem of Allocating Choice," Proceedings of the American Philosophical Society 112, no. 2 (April 1968): 105-6.

${ }^{34}$ Although this is not the place to discuss this point in any detail, Fuller has offered a version of Hegel's master/slave argument from the Phenomenology of Spirit. There, Hegel describes the evolution of relationships of pure dependency (of the slave on the master, who holds the power of life and death over him) to relationships of reverse dependency (as the master comes to rely on the slave, who takes over the active role, playing Jeeves to the
} 
Fuller describes his theory as an interactional view of law ( $M L$ 221), because in his view the choice of law over managerial direction implies a moral relationship between governors and the governed based on mutuality (ML 209, 216).

Government says to the citizen in effect, "These are the rules we expect you to follow. If you follow them, you have our assurance that they are the rules that will be applied to your conduct." When this bond of reciprocity is finally and completely ruptured by government, nothing is left on which to ground the citizen's duty to observe the rules. (ML 39-40)

This is an entirely different moral relationship than that of managerial direction - "the basic relation of order-giver and order-executor" ( $M L$ 209) - although even managerial direction creates some reciprocity. Interestingly, Fuller insists that within the managerial context, the canons of clarity, noncontradictoriness, obeyability, constancy through time, and publicity really are principles of efficacy and nothing more (ML 208-9); the clear implication of this point is that he believes that these canons have a different status in the context of law. There, they are professional virtues of the lawgiver, part and parcel of the mutual respect that Fuller believes is at the heart of the relationship between a lawmaker and those whom she governs.

In what sense are canons like clarity, noncontradictoriness, or constancy through time professional virtues of the lawgiver? Consider a group of people who wish to go into business together, and who retain a lawyer to draw up a partnership agreement that reconciles the divergences that inevitably exist among their interests. The partners are entrusting their joint venture to the lawyer; they are counting on the lawyer's professional ability to craft an agreement that will provide a workable architecture for their enterprise. If the partnership agreement turns out to be unclear, self-contradictory, or incapable of execution, this is betrayal, not just incoherence or "inefficacy." 35 The partners will suffer for the

master's increasingly infantile and incompetent Bertie Wooster) and, later, to relationships of reciprocity. G. W. F. Hegel, The Phenomenology of Spirit, trans. A. V. Miller (Oxford: Oxford University Press, 1977), 111-19.

${ }^{35}$ Indeed, all of these infirmities are breach-of-contract defenses at common law: they void at least the afflicted clauses of the instrument. When we notice this, and recall that Fuller was a contracts scholar, it is tempting to argue that Fuller derived the canons by asking himself what conditions are necessary for a valid social contract between governors and the governed. Recall in this connection the passage quoted above, in which government "makes an offer" to citizens: "These are the rules we expect you to follow. If you follow them, you have our assurance that they are the rules that will be applied to your conduct." This sounds a great deal like a social contract. It is noteworthy as well that when Fuller discusses total failure to abide by the canons, he writes, "[i]t results in something that is not properly called a legal system at all, except perhaps in the Pickwickian sense in which a void contract can still be said to be one kind of contract." ML 39, emphasis added. 
lawyer's fecklessness. Those who claim that Fuller's canons merely represent conditions of efficacy appear to overlook this point when they emphasize that a ruler who violates the canons will be unable to accomplish his aim, as though the point of the ruler's activity is only to accomplish his own aim, rather than the aims of those he rules. It is this, perhaps, that leads Fuller repeatedly to accuse his critics of viewing government "as a one-way projection of authority" (ML 204).

We can be more specific about how the eight canons are virtues of lawmaking. The two most fundamental-the canons that distinguish the law-giving enterprise from managerial control-are the canons of generality and congruence between rules and their enforcement. The former insists that governors give directions in the form of general rules; the latter demands that they treat those rules as binding on themselves as well as on the governed, in the sense that they will not depart from the rules they have announced. ${ }^{36}$ The commitment to bind the governed only through general rules that also bind the lawmaker establishes the moral relationship of reciprocity between governors and the governed. These two canons are moral commitments that define the enterprise as lawgiving rather than something else.

The remaining six canons fall into two natural groupings: precepts of clear communication and precepts of reasonable expectation. Once the lawmaker has undertaken to govern through general rules binding on both her and the governed, she must announce the rules to the governed, and she must ensure that her rules are ones that the governed may reasonably be expected to follow. Rather obviously, the canons of clarity and publicity are aspects of clear communication, while the canons of constancy and obeyability are aspects of reasonable expectation. The remaining canons-nonretroactivity and noncontradictoriness-may be regarded as aspects of both clear communication and reasonable expectation. A rule requiring me to do something today is not adequately communicated if it is not issued until tomorrow, nor is it reasonable to expect me to abide by it; likewise, a self-contradictory rule conveys nothing (because anything follows from a contradiction), and cannot be obeyed.

The burden of understanding and complying with rules falls on those whom the rules govern; the reciprocal relationship between governors and the governed places a corresponding burden on the governor to make the rules understood and capable of being complied with. That, ultimately, is why clear communication and reasonableness are moral virtues of the lawmaker.

\footnotetext{
${ }^{36}$ A manager may also issue orders in the form of general directives-rules-but remains at liberty to depart from the directives when circumstances require. In the terminology of Rawls's "Two Concepts of Rules," the manager adopts a "summary conception" of rules, whereas the lawmaker adopts a "practice conception." John Rawls, "Two Concepts of Rules," in Rawls, Collected Papers, ed. Samuel Freeman (Cambridge, MA: Harvard University Press, 1999), 34-39.
} 


\section{V. "'Discovery' in the Moral Realm"}

Why does Fuller call his view "natural law"? Fuller energetically rejects the traditional idea that natural law represents "higher law" ( $R F C L$ 379, $M L 96, R N$ 84), and indeed he suspects that the appeal to higher law is an unfortunate residue from positivism (PFL 656, 659-60). Strikingly, he attributes no authority to laws as such: like a good legal realist, he argues that judges should treat statutes and precedents simply as "one [more] of the realities the judge must respect in making his decisions" (RFCL 380)-in other words, as constraints within which judicial problem-solving must maneuver, not as authorities to which judges must defer. If Fuller had never employed the term "natural law" in connection with his views, we might be hard-pressed to guess that his is a natural law jurisprudence.

Fuller's pronouncements about natural law do not help much. "I discern ... one central aim common to all the schools of natural law, that of discovering those principles of social order which will enable men to attain a satisfactory life in common. It is an acceptance of the possibility of 'discovery' in the moral realm that seems to me to distinguish all the theories of natural law from opposing views" (RN 84). Talk of the possibility of discovery in the moral realm makes it sound as if Fuller equates natural law theory with moral realism. But moral realism, the thesis that moral judgments are objective and referential, is not distinctive to natural law. Positivists, who believe that law can and should be open to moral criticism, can accept the realist thesis without difficulty. Indeed, many of the positivists were utilitarians, and utilitarians hold that judgments of right and wrong-claims about which actions are utility-maximizing and which are not-are objective and referential.

Elsewhere, Fuller cautions that "for many the term 'natural law' still has about it a rich, deep odor of the witches' cauldron" (RFCL 379). But all it really signifies, he says, is

that there are external criteria, found in the conditions required for successful group living, that furnish some standard against which the rightness of ... decisions should be measured.... Certainly it would never occur to him [the natural lawyer] to describe the natural law he sought to discover, and felt bound to respect, as a "brooding omnipresence in the skies." Rather for him it would be a hard and earthy reality that challenged his best intellectual efforts to capture it. The emotional attitude ... would not be that of one doing obeisance

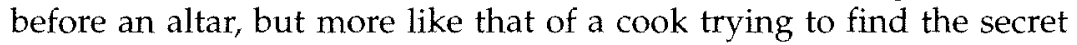
of a flaky pie crust.... (RFCL 379)

Once again, there is nothing here that a utilitarian positivist could not enthusiastically embrace. Like Fuller, the utilitarian positivist is an ethical 
naturalist, who believes that deciding what the law ought to be is hard intellectual work, with external standards of success determined in large part by empirical facts about nature and human nature.

I believe, however, that once we think of Fuller's theory as the professional ethics of lawmaking, we find a coherent answer to the question of what makes it a natural law theory: it derives moral requirements of the lawmaker's job from features unique to the lawmaking enterprise. Unlike other natural law theories, however, the morality implicit in Fuller's concept of law is the morality of lawmaking, not of the law made.

Fuller complains that positivists neglect the distinctive role-morality of lawmaking: "If the lawgiver enacts what Hart calls 'iniquitous' laws, he sins of course against general morality, but there is no special morality applicable to his job itself" (ML 193). This description is plainly true of utilitarianism, which regards a job as nothing more than a causal path connecting an agent's input to output in the form of utility, the way that a transmission connects an auto's engine to its wheels. The utilitarian would regard the role-morality of a job as nothing more than an application or instantiation of the principle of utility. For Fuller, however, it is a fallacy "to assume that moral precepts retain the same meaning regardless of the social context into which they are projected" ( $M L$ 207); he accuses both utilitarians and Kantians of this fallacy (PSO 201). What both overlook, Fuller argues, is that when you take on a job, intending to pursue it in a way that respects general morality, you discover that the job creates moral expectations of its own (PSO 200-201). Fuller's arguments about the morality of law are meant to show that lawmaking has its own distinctive virtues (conformity to the eight canons) and its own distinctive moral outlook (respect for the self-determining agency of the governed), both of which follow from the nature of the lawmaking enterprise and not directly from general morality.

This is what Fuller has in mind when he writes about discovery in the moral realm. He is not tendering a general commitment to moral realism, but rather making the more specific claim that institutions, particularly legal institutions, although they are entirely human creations, have moral properties of their own-properties that their designers may never have intended or even thought about, and that are connected only indirectly to general morality. Identifying the morality of institutions, the virtues and vices of participating in them, is a matter of discovery, not invention - a matter of reason rather than fiat.

I think Fuller is right. We can observe these phenomena in the evolution of games like baseball. Games are in one sense an entirely positivist creation: the rules define the game, and presumably, if the rules permit a practice, engaging in it cannot be cheating. One might argue that the game would be better if the rules forbade certain practices - in positivist terms, that the game as it is isn't the game as it ought to be. But as long as the rules do not favor one team over the other, abiding by these rules 
cannot be criticized on the ground that it is not a fair way to play baseball. So goes the positivist argument.

Yet in actuality, the rules of baseball have been modified repeatedly over the years because as the game develops, it becomes clear that some behavior permitted by the rules really is cheating. Fielders intentionally miss infield pop-ups when there are runners on first and second base, in order to get an easy double play; pitchers make the ball curve by spitting on it; base runners block batted balls with their bodies to prevent fielders from making a play; hitters peek at the catcher to see whether he is setting up for an inside or outside pitch; batters with two strikes against them intentionally swing and miss at wild pitches so they can run safely to first base when the ball flies past the catcher. All of these practices were at one time permitted by the rules, and the first three were banned - not because the game would be better if they were banned (though this is true), but because it became clear that missing infield flies to get the cheap double play, throwing the spitter, and interfering with batted balls were forms of cheating. These were moral discoveries about baseball-playing, of just the kind that Fuller claims to have made about lawmaking. They are part of the natural law of an artificial institution. Interestingly, no rule currently forbids batters from peeking at the catcher to see where he is setting up. However, if the opposing players catch him in the act, the batter will be hit by a pitch his next time up, and no one will complain, because even the batter knows he deserves it. He has violated the natural law of baseball. ${ }^{37}$ The same goes for the batter with two strikes against him who swings at a wild pitch: one writer recalls that when he did this in high school, his own teammates shunned him afterward. ${ }^{38}$

One might object that these practices are cheating not because they violate the "natural law of baseball," but merely because the written rules did not do a good enough job of codifying the game as it was supposed to be played. But no one knew a priori how baseball was supposed to be played; refining the rules was not merely a means to the end of preserving the original intent of baseball's framers. The discovery that throwing the spitball is a form of cheating was simultaneously a discovery about the point of the contest between batter and pitcher. The relationship is dialectical, not hierarchical.

${ }^{37}$ See Keith Hernandez and Mike Bryan, Pure Baseball: Pitch by Pitch for the Advanced Fan (New York: HarperCollins, 1995), 125-27. Interestingly, Hernandez (an all-star first baseman) states both that the peeker deserves to be hit by a pitch and that peeking is neither cheating nor bad sportsmanship. That is because Hernandez believes that nothing, not even practices forbidden by the rules, is unfair if the other team or the umpires have a fair opportunity to catch and punish the players who engage in it. His is a legal realist view of cheating, desert, and self-help, quite distinct from both natural law and positivism.

${ }^{38}$ Ted Cohen, "There Are No Ties at First Base," Yale Review 79, no. 2 (October 1990): 321-22. "[My teammates] did not care for what I had done. ... They regarded me as someone who did not really grasp the nature of the game. I thought that in knowing the rules I knew the game; they knew the game in some other way." Ibid., 322. I am grateful to David Brink for calling Cohen's hilarious essay to my attention. 


\section{The Progressive Positivists' Critique of Natural Law}

I now turn to criticisms of Fuller's view. In his review of The Morality of Law, Hart wonders whether he and Fuller are perhaps "fated never to understand each other's work," ${ }^{39}$ and on one central issue it seems clearly true that Fuller and his positivist critics talk past each other. This is the curious issue of which theory provides its adherents with the morally superior point of view on the law. The issue is curious, of course, because ordinarily we think that theories should be chosen on the basis of whether they are correct, not whether they morally improve their adherents. Nevertheless, the argument turns out to be an important one both for Fuller and his critics. ${ }^{40}$

Let us put it most directly. Fuller repeatedly accuses positivists of being statists, "overprimed with power" (PSO 277); theirs, he says, is "the view that identifies the lawyer's work with established state power" (PSO 252). And repeatedly, progressive positivists like Fred Schauer, Neil MacCormick, and Robin West level the identical accusation of statism against natural lawyers. ${ }^{41}$ (By progressive positivists, I mean positivists who deny per se moral authority to the legal status quo and therefore to the state.) According to Schauer, "the classical natural law theorist" believes "that the very existence of a legal system ... provides ... assurance that the legal system has been designed either to incorporate moral criteria or to produce morally desirable ends." 42

This argument between natural lawyers and progressive positivists originates in one of the most important passages in Hart's half of the debate with Fuller. In "Positivism and the Separation of Law and Morals," Hart accuses natural lawyers of having only "half digested the spiritual message of liberalism." ${ }^{33}$ Natural lawyers understand that in the face of evil enactments by the state, individual conscience prevails over the duty to obey. This is the spiritual message of liberalism. But natural lawyers have only half-digested it, because it seems that the only way

${ }^{39}$ Hart, "Book Review - The Morality of Law," 1281.

${ }^{40}$ See Philip Soper, "Choosing a Legal Theory on Moral Grounds," in Jules Coleman and Ellen Frankel Paul, eds., Philosophy and Law (Oxford: Basil Blackwell, 1987), 31-48.

${ }^{41}$ See Frederick Schauer, "Positivism Through Thick and Thin," in Brian Bix, ed., Analyzing Law: New Essays in Legal Theory (Oxford: Clarendon Press, 1998), 65-78; Schauer, "Fuller's Internal Point of View," 305-12; Frederick Schauer, "Constitutional Positivism," Connecticut Law Review 25, no. 3 (Spring 1993): 805-7; Frederick Schauer, "Positivism as Pariah," in Robert P. George, ed., The Autonomy of Law: Essays on Legal Positivism (Oxford: Oxford University Press, 1996), 31-55; Neil MacCormick, "A Moralistic Case for A-Moralistic Law," Valparaiso Law Review 20, no. 1 (Fall 1985): 10-11; Robin West, "Three Positivisms," Boston University Law Review 78, no. 3 (June 1998): 791-812; and Robin West, "Natural Law Ambiguities," Connecticut Law Review 25, no. 3 (Spring 1993): 831-41. West, it should be noted, expounds the progressive positivist view sympathetically without wholly endorsing it.

${ }^{42}$ Schauer, "Positivism Through Thick and Thin," 70.

${ }^{43}$ Hart, "Positivism and the Separation of Law and Morals," 618; Hart, The Concept of Law, $205-6$. 
they can license disobedience is by denying that evil enactments are law. Apparently, they cannot shake off the idea that law must be obeyed. In legal philosopher Donald Regan's felicitous phrase, they still think that law has a halo. ${ }^{44}$ This is the illiberal side of natural law.

Positivists, according to Hart, are morally more clear-headed. They understand that law has no necessary moral content, no halo. They labor under one less illusion about where their moral duty lies, and are less likely to accede to bad law merely because it is law. Quoting Schauer once again, "in insisting that the concept of law does no moral work the [progressive positivist] is taking the irreducibly moral position that we ought not to expect our understanding of law and legal institutions to carry any of the moral water when we engage in personal decision-making or institutional design." 45

It is very curious to find a natural lawyer like Fuller and progressive positivists like Hart and Schauer each accusing the other side of being too statist -in effect, each is trying to outflank the other on the left (which of course leads battlefield adversaries to revolve in a perpetual circle around a point of engagement that neither ever reaches). At least one side in this debate is failing to grasp something about the other's position. In this case, I think, both are.

Let us begin with Fuller's accusation that positivists identify law with "a one-way projection of authority, originating with government and imposing itself upon the citizen" (ML 204). This is only half-true, because positivists argue only that legal systems may be one-way projections of state authority, not that they must be. Even if the accusation were true, though, Fuller wrongly supposes that positivists approve of one-way projections of state authority. Hart's argument, of course, is that when the law authorizes something evil, a liberal positivist will disapprove and disobey.

Next, look at the progressive positivists' moral critique of natural law. Schauer, recall, argues that for classical natural law theorists, the very existence of a legal system ensures its morality. Why should that be? Schauer offers no argument, but evidently he believes that the classical theorists contrapose the natural law maxim "unjust law is not law" into the claim that law is just. However, natural lawyers do not actually make this mistake in contraposition. The natural law maxim is shorthand for "unjust positive law is not genuine law." This is logically equivalent not to the claim that (all) law is just, but to the claim that positive law that is also genuine law is just. ${ }^{46}$ The mere existence of positive law leads to no conclusion whatever about its justice or injustice.

${ }^{44}$ Donald H. Regan, "Law's Halo," in Coleman and Paul, eds., Philosophy and Law, 15-30.

45 Schauer, "Positivism Through Thick and Thin," 70.

46 Among the progressive positivists, West is clear about this. She regards these two ways of reading the natural law maxim as an ambiguity in natural law theory, whereas I regard them as a positivist misunderstanding of natural law. 
Let me rephrase all this in a more polemical and less logic-chopping manner. Progressive positivists like Hart, MacCormick, and Schauer think that the natural law maxim will confuse its adherents and make them too impressed with law, too complacent with the status quo, and too likely to obey. But of course, "unjust law is not law" is the traditional argument for disobedience, not obedience-so who exactly is it who is confused? In its most famous contemporary American incarnation, the natural law maxim figures prominently in Martin Luther King's "Letter from Birmingham City Jail," where King invoked it to explain, in the most stirring terms, why he was right to disobey a court order forbidding a 1963 civil rights march. ${ }^{47}$ If the progressive positivists think that the natural law maxim is an invitation to complacency and obedience, then they must believe that King misunderstood the maxim, because he was neither complacent nor obedient. King misunderstood the maxim, apparently, by failing to draw the wrong conclusion from it. Isn't it more likely that the progressive positivists have misunderstood why natural lawyers like King insist that unjust law is not law?

The positivist moral critique of classical natural law misfires in a slightly different way against Fuller's version. The progressive positivists fear that anyone who believes in "the morality of law" will illicitly regard legal enactments as having already passed a preliminary threshold toward moral acceptability. As we have seen, Fuller thinks just the opposite. For Fuller, to call something law entails that it has extra moral demands placed on it by virtue of the "morality of law" -the role-morality of law-giving. Law's halo, on Fuller's account, provides additional grounds for criticizing law, not for obeying it.

In this respect, at any rate, Hart and Fuller were talking past one another. Notice, for example, that when Fuller speaks of "fidelity to law" (in PFL) he is generally talking about officials' professional obligation to maintain the legal system in good order, not about the citizen's obligation to obey the law, which is Hart's topic. Fuller asks how German judges, not ordinary Germans, should have responded to the Third Reich, and he answers that fidelity to law - which is not the same as obedience to lawshould have led them to resist.

In a recent essay, Schauer offers a different criticism of Fuller, one which presents an interesting twist on the progressive positivist argument. Schauer focuses on the fact that Fuller's is "insider jurisprudence," designed and built to help conscientious legal professionals become better lawyers. In the terms I have been urging, it is jurisprudence in the service of professional ethics. Schauer accurately remarks that "Fuller's perspective flows smoothly from his role as a legal theo-

\footnotetext{
${ }^{47}$ Martin Luther King, Jr., "Letter from Birmingham County Jail," reprinted in King, Why We Can't Wait (New York: Mentor, 1964), 76-95.
} 
rist explicitly seeing himself located in a law school and speaking to actual or would-be lawyers." ${ }^{48}$ Insider jurisprudence presupposes that the professional project has worth, and is worth the efforts of conscientious people to improve it.

Suppose, however, that one is an outsider, whose question is not "What kind of lawyer shall I be?" but "Why should anyone be a lawyer?" ${ }^{9}$ An outsider need not begin by supposing that the legal system has any worth at all, but she does need to understand what the legal system is. For the outsider, then, positivism is the superior starting point, for only positivism facilitates the project of "first ... characterizing the legal system, and then ... morally evaluating it." 50

To illustrate Schauer's point, let our outsider be a visitor newly arrived in a foreign country, who asks someone, "What is the legal system like?" (Perhaps she is thinking about emigrating to the foreign country and going to law school.) And suppose the answer is this: "The judges do whatever the regime tells them to, the regime is repressive, the lawyers are not allowed to disagree with the judges, the laws are vague and change all the time, and the schedule of criminal penalties is a state secret." If a Fullerian overhearing the conversation chimes in, "You see, it isn't a legal system at all!" the outsider will reply, "Call it whatever you like-but the person I just talked with answered the question $I$ am interested in." The outsider has rightfully asked a positivist question and gotten a positivist answer. If the outsider had instead approached the Fullerian to ask "What is the legal system like?" and received the answer, "There is no legal system here," this answer would be misleadingly coy, and in no way more truthful.

Nor is "There is no legal system here" a caricature of Fuller's way of talking. In his reply to Hart, Fuller quotes a Hitler-era statute against slandering the Nazi Party, deems it a "legislative monstrosity," and then embraces the view of postwar German courts that "saw fit to declare this thing not a law" (PFL 654, 655). Schauer's point, I take it, is that there is a straightforward "positivist" sense, glossed over by Fuller, in which the statute is a law (and not, say, a poem). Otherwise, how could Fuller call it a "statute" and declare it a legislative monstrosity?

Embedded in Schauer's argument we find a claim that Fuller denies: that the insider's concept of law, which Schauer agrees is and should be a moralized one, is unnecessary to describe a society's legal institutions-a "positivist" description is available. The examples just presented make

48 Schauer, "Fuller's Internal Point of View," 305.

49 Tbid., 308.

50 Ibid., 309-10. In "Positivism Through Thick and Thin," Schauer remarks that he finds it no coincidence that among three of the austerest positivists-himself, Jules Coleman, and David Lyons - "two do not possess law degrees and the third no longer teaches primarily in a law school." Schauer, "Positivism Through Thick and Thin," 70 n. 1. 
this seem plausible, but Fuller would not be without a response. It would go, I take it, as follows. ${ }^{51}$

'Lawmaking' is a purposive concept, and the purpose of lawmaking is to subject human conduct to the governance of rules (ML 146). Like all purposive concepts, it contains implicit criteria of success and failure. As we have seen, lawmaking creates a moral relationship between governors and the governed, and successfully carrying out the terms of that relationship is part of what succeeding at lawmaking means. It follows that if our outsider can recognize what her informant has described as a legal system at all, she can, and indeed must, recognize it as a deviant legal system. Its servile judges, repressive rulers, gagged lawyers, vague and inconstant rules, and secret punishments represent a gross deviation from the aspirations inherent in the lawmaking enterprise.

Could the positivist resist this conclusion by declining to describe legal systems purposively? This is easier said than done. When the outsider asks "What is the legal system like?" she must have in mind some concept of what a legal system is, for not just anything can count as a legal system. If the informant answers the outsider's question by saying, "People wander through the countryside gathering grapefruit, which they sell in the marketplace," the outsider would not think, "My, what an unusual legal system." She would instead draw the Davidsonian conclusion that she and her interlocutor are not understanding each other's words properly. ${ }^{52}$ And she would draw that conclusion because what the informant has described does not do, badly or otherwise, what legal systems do-thus, her informant cannot be talking about a legal system.

An outsider's description of an alien legal system is implicitly a comparison of that system with her, and our, concept of what a legal system is and is for. Such a concept is an insider's purposive concept. The idea that one can dispense with the internal perspective on legal systems turns out to be untrue, because we need the internal perspective-our understanding of the point of a legal system-in order to recognize a legal system when we encounter one. Even the outsider's viewpoint on a legal system presupposes the priority of the purposive point of view.

It may be thought, however, that all these arguments overlook the progressive positivists' most basic concern, which is simply that insider jurisprudence lacks critical bite. For a critique of human sacrifice you do not turn to the priest-not even the ethical priest who treats the victim

${ }^{51}$ In the arguments that follow, I am drawing freely from (and modifying in part) $L Q I$ and $R N$. Interestingly, Ernest Nagel offered an argument very similar to Schauer's thirty-five years earlier. Ernest Nagel, "On the Fusion of Fact and Value: A Reply to Professor Fuller," Natural Law Forum 3, no. 1 (1958): 79.

52 Donald Davidson has for many years defended the so-called "principle of charity" in linguistics, a rule of thumb which states that if your translation of a foreigner's utterances implies that the foreigner has crazy beliefs, the fault lies in your translation. Donald Davidson, Inquiries into Truth and Interpretation (New York: Oxford University Press, 1984), xvii, 196-97. 
with impeccable concern and respect, at least until the altar is ready. Lawyers, it might be feared, are like these priests. They have too much invested in their system to seriously contemplate major revisions. Furthermore, lawyers' knowledge is system-specific local knowledge, and the sheer desire for epistemic comfort, the fear of the unknown, may well block lawyers from grasping that entire continents of their legal system are unjust or dysfunctional.

This may be so, but precisely the same things might be said of nonlawyers. Unjust laws are seldom only legal injustices. They typically represent the moral views of dominant or once-dominant groups in the larger society - what King, in his Birmingham letter, accurately described as the "numerical or power majority group." Nonlawyers who belong to a system's numerical or power majority group are beneficiaries of the system just as lawyers are, and they are no less likely to confront epistemic vertigo at the prospect of abandoning the familiar evils and the moral beliefs that ratify them.

Perhaps, then, the authentic outsider's standpoint is that of the victims of unjust laws. However, victims are usually cut off from access to information about how their oppressive legal system operates, and in many cases are also denied the basic goods of education. Historically, the great social and legal critics have been insiders or semi-insiders whose lively sense of critical morality allows them to pass beyond their own selfinterest and identify with the victims of bad law. I see no reason to suppose that legal insiders will have a weaker sense of critical morality than outsiders. Are legal professionals like Thurgood Marshall or Catharine MacKinnon really at a disadvantage in diagnosing bad law? Worse at it than Malcolm X or Andrea Dworkin? There is no reason to suppose anything of the kind.

\section{VII. "A Brutal Indifference to Justice and Human Welfare"}

And yet there does seem to be something amiss in Fuller's theory, something too quick and easy in the way it concludes that an immoral lawmaker is not just letting down his subjects, but is also betraying the very idea of law. As we have seen, Fuller argues that the enterprise of subjecting human conduct to the governance of rules presupposes a moral relationship between governors and the governed - a moral relationship aimed at promoting the self-determining agency of the governed. From this relationship, it follows that the eight canons are moral excellences, not just rules of efficacy. All this seems like an awful lot to derive from the bare concept of people governing other people through rules. Fuller has pulled a very large rabbit out of a very small hat. His theory seems too good to be true.

I wish to suggest that it is too good to be true. Like Schauer, I trace Fuller's overoptimism about the law to his insider perspective. This is 
not, however, because of the generalized worry about insiders that I have just discussed. The problem is not with insider jurisprudence as such, but with the fact that Fuller's insiders are lawyers. Quite simply, the lawyer's role is more problematic than Fuller admits.

At one point, Fuller throws out a challenge to his doubters, rhetorically asking whether "history does in fact afford significant examples of regimes that have combined a faithful adherence to the internal morality of law with a brutal indifference to justice and human welfare" (ML 154). He plainly believes that the answer is "no," but I begin my argument by suggesting that the answer is "yes" in almost every regime that has ever existed. This is because almost every regime that has ever existed has legislated expressly to deny the self-determining agency of women, and has thereby denied what Fuller claims is the substantive morality imminent in law. Until the most recent times in a bare handful of nations, women have enjoyed few or no political rights, have been classified as property or quasi property, and have been subjected by law to the tutelage of their husbands and fathers. One might offer analogous examples drawn from the histories of slavery or legally explicit ethnic subjugation. (Would Fuller deny that the American law of slavery adhered rather well to the internal morality of law? On what grounds?) However, I think that the for-all-practical-purposes-universal legal subjugation of women offers the most striking example of what goes wrong in Fuller's theory. ${ }^{53}$

The important point, it seems to me, is this. Fuller maintains that any legal regime that abides by the eight canons will respect the selfdetermining agency of those to whom its rules are addressed; so far as it goes, his argument is profound and correct. But it does not go as far as Fuller hoped, because he overlooks an important qualification: those whose self-determining agency law aims to further need not include the entire population subject to the law, because the rules may really be addressed only to a numerical or power majority (to borrow King's words once again). That is, it may well be that the legal edifice of patriarchy aims to enhance the self-determining agency of men. But it does so at the expense of women, who are subject to the tyranny (or, at best, the managerial direction) of their husbands and fathers. Justice for the guys coexists with injustice for women.

The crucial condition under which this form of mixed justice and injustice can exist is that the dominant group is able to exert direct control over the subordinate group by virtue of living side-by-side with them. To take a straightforward illustration, legal regulation of slaveholders, es-

${ }^{53}$ One might object that regimes of slavery or ethnic/gender subordination violate the canon of generality, and hence they are not genuine rule-of-law regimes. However, generality does not mean that identical laws apply to everyone. It means only that when a rule classifies people, it applies equally to everyone in the specified class. For example, a rule forbidding married women from forming binding contracts without their husbands' permission would satisfy the generality requirement if it applied to all married women. 
tablishing a framework of general rules that advances and respects their self-determining agency, turns out to be wholly consistent with tyrannical or managerial regulation of slaves. In just the same way, patriarchal legal orders enhance the self-determining agency of men in part by enhancing their license to exert unfettered authority over women. The problem, it seems, is that even though both men and women fall under the law's jurisdiction, the law excludes women from the community whose freedom it aims to enhance.

I can find no evidence that Fuller ever considered the catastrophic asymmetry between whom the law binds and whom the law helps, nor the implications for his jurisprudence of the law's exclusion of women from the community of freedom. He was certainly aware, though, of the "basic question": "Who is embraced in the moral community?" - that is, "Who shall count as a member of the in-group?" (ML 181). He was, after all, writing during the heyday of the civil rights movement.

Within a given political society there are men commonly described as being of different races. These men have lived together for many years. ... They have together produced a common culture. Is there no moral principle that can imperatively condemn drawing a line between them, and denying to one group access to the essentials on which a satisfactory and dignified life can be built? (ML 183)

Fuller recognizes that he needs an affirmative answer to this question, but the one he provides is unsatisfying, except perhaps as rhetoric. He cites the parable of the Good Samaritan and a famous Talmudic aphorism to argue "that we should aspire to enlarge that community [the moral community] at every opportunity" ( $M L 183$ ), because the morality of aspiration "cannot refuse the human quality to human beings without repudiating itself" (ML 183). Confusingly, Fuller asserts that these are propositions from the morality of aspiration that are fully as imperative as duties. So far as I can tell, Fuller provides no reason for supposing that the scriptures he cites truly set out the morality of aspiration, or for thinking that cosmopolitan aspirations have the force of duties, or for assuming that cosmopolitanism belongs to the morality of law as Fuller understands it-namely, the professional ethics of lawgivers and law-appliers. Fuller seems to have forgotten his own distinction between criticizing bad laws on general moral grounds, which he disfavors, and criticizing them as violations of the distinctive role-morality of the legislator, a practice of which he approves.

He cannot, for example, really mean that any lawmaker who enacts sexist or racist legislation has violated the role-morality of the legislator's craft. The legislative role-morality surely does not contain an equal protection clause built in a priori. If anything, the argument seems more plausible going the other way: perhaps legislators have a role-obligation 
to enact laws that they find morally objectionable if those laws truly codify the dominant morality of the society. ${ }^{54}$ Tennyson's ultracosmopolitan Ulysses ("I am a part of all that I have met"), having returned from his wanderings to govern the cultural backwater of Ithaca, understands that only "slow prudence" will be able "to make mild a rugged people, and thro' soft degrees subdue them to the useful and the good." In the meantime, "I mete and dole unequal laws unto a savage race." 55 Unequal laws, apparently, are all that a savage race can handle, and a conscientious lawmaker will not jump the gun. This argument may be wrong: there is a genuine question about whether a professional's role-morality can override the demands of universal morality. ${ }^{56}$ But even if the answer is no, the reason that it is no is because of the priority of the universal over the particular, not because the demands of universal morality are built into the structure of role-morality a priori, for legislators or anyone else.

Fuller is indulging in wishful thinking. He wishes that lawmaking were inherently cosmopolitan, because his argument requires a cosmopolitan solution to the problem of defining the moral community. He confronts a familiar problem in legal ethics. His lawmakers, we have seen, are like transactional lawyers, aiming to facilitate their clients' interactions with a well-crafted structure of rules. But transactional lawyers have clients, and there are limits to how far lawyers can take into account the interests of nonclients. Even when transactions require reciprocity between clients and other parties, each lawyer's primary loyalty runs to her own clientand none of the lawyers may pay attention to the interests of parties who are not part of the transaction at all, regardless of whether the transaction affects those parties' vital interests. The Fullerian legislator is like a transactional lawyer whose "client" is the numerical or power majority in the community; and, as in the case of the lawyer, there is a tension between legislating on behalf of the client's interest and legislating on behalf of everyone's interest.

In his many writings on the adversarial ethics of the legal profession, Fuller made it clear that he was aware of the problem that advancing client interests may not be in the public interest; but he never found a successful solution to it. ${ }^{57}$ That is because no successful solution can be found. Proving that the pursuit of special interests is identical to the

\footnotetext{
54 That, at any rate, was Oliver Wendell Holmes's conclusion. "[T]he proximate test of good government is that the dominant power has its way," he wrote, and "legislation ... should modify itself in accordance with the will of the de facto supreme power in the community." The first quotation comes from "Montesquieu," in Oliver Wendell Holmes, Collected Legal Papers (New York: Peter Smith, 1952), 258; the second, from Oliver Wendell Holmes, "The Gas-Stokers' Strike," Harvard Law Review 44, no. 5 (March 1931): 796.

${ }^{55}$ Alfred, Lord Tennyson, "Ulysses," in Robert Penn Warren and Albert Erskine, eds., Six Centuries of Great Poetry (New York: Dell, 1955), pp. 411-12, 11.3-4, 18, 36-38.

${ }^{56} \mathrm{I}$ have offered an extended treatment of this question in my Lawyers and Justice: An Ethical Study (Princeton, NJ: Princeton University Press, 1988), chaps. 6 and 7.

${ }^{57} \mathrm{I}$ argue this in detail in "Rediscovering Fuller's Legal Ethics," 819-29.
} 
pursuit of general interests is like squaring the circle. It is a problem that political philosophers have always wrestled with-Kant argued that the interests of male property-holders are suitably universal, Hegel entered the same claim for bureaucrats, Marx for the proletariat, György Lukács for the Communist Party, and innumerable patriarchs for the menfolk. History has been unusually generous in providing counterexamples to their theories. Civic republican constitutional theorists have in recent years made the claim of universality on behalf of judges ${ }^{58}$ But Fuller is perhaps the only philosopher to do so on behalf of lawyers. ${ }^{59}$ That is one of his great strengths; no one, it seems to me, has thought more deeply or perceptively about the services of lawyers in the liberalization of societies. But (let's face it) lawyers aren't that good.

\section{Law and Philosophy, Georgetown University Law Center}

\footnotetext{
58 See, for example, Frank I. Michelman, "Foreword: Traces of Self-Government," Harrard Law Review 100, no. 1 (November 1986): 4-77; and Cass R. Sunstein, "Interest Groups in American Public Law," Stanford Law Review 38, no. 1 (November 1985): $29-87$.

59 Talcott Parsons, however, argued that lawyers play a central role in mediating between public interests (represented by the law) and private interests (those of clients). See Talcott Parsons, "A Sociologist Looks at the Legal Profession," in his Essays in Sociological Theory. rev. ed. (New York: Free Press, 1954), 370-85. In some ways, his structural-functionalist argument was anticipated by Tocqueville in his famous chapter on lawyers as the American aristocracy in Democracy in America. Alexis de Tocqueville, Democracy in America, ed. J. P. Meyer, trans. George Lawrence (Garden City, NY: Anchor Books, 1969), chap. 8, 1:263-70. For discussion of the Tocqueville-Parsons tradition, see my "The Noblesse Oblige Tradition in the Practice of Law," Vanderbilt Law Review 41, no. 4 (May 1988): 717-40.
} 